\title{
IMPROVEMENT OF STEEL SHEETS' CORROSION RESISTANCE BY APPLICATION OF NEW GENERATION COATINGS
}

\author{
${ }^{1}$ Emil EVIN, ${ }^{1}$ Miroslav TOMÁŠ, ${ }^{2}$ Ján KEPIČ \\ ${ }^{1}$ Technical University of Košice, Košice, Slovak Republic, EU, emil.evin@tuke.sk,miroslav.tomas@tuke.sk \\ 2 Institute of Materials Research of SAS, Košice, Slovak Republic, EU, jkepic@saske.sk
}

https://doi.org/10.37904/metal.2020.3546

\begin{abstract}
Besides customers and environmental requirements such as safety increase, the weight and emission reduction, and the life-time improvement, huge role plays corrosion resistance of the car-body components. This is improved by applying $\mathrm{Zn}$-based coatings on the steel sheets. In the article are presented results of corrosion tests performed on the steel sheets with $\mathrm{Zn}$-Al-Mg coatings applied. These are compared to the standard $\mathrm{Zn}$ coating. Samples were deformed by Erichsen stretching test and by 3-point bending tests to the angle of $90^{\circ}$ and $180^{\circ}$. After that, these were exposed to salt spray in the corrosion chamber. The limit criteria were time to red corrosion appearance and percentage of corroded surface evaluated on time. The results showed the small amount of $\mathrm{Al}$ and $\mathrm{Mg}$ improved the corrosion resistance of $\mathrm{Zn}-\mathrm{Al}-\mathrm{Mg}$ coatings when compared to the conventional $\mathrm{Zn}$ coating.
\end{abstract}

Keywords: Zn based coatings, steel sheet, corrosion resistance, strain, Erichsen test, bending test

\section{INTRODUCTION}

The life of the car is largely limited by the life of the body. Car manufacturers strive to prevent perforation corrosion for ten years and cosmetic corrosion of the car body for five years. In order to meet these requirements, materials with multifunctional coatings of zinc, tin, aluminum, lead, nickel and chromium are being developed. Due to the relation between customer requirements and price, zinc-based coatings, which can be made by various processes, have an irreplaceable place among coated steel sheets in the automotive industry [1,2]. Improvement of the corrosion resistance of the zinc layer can be achieved by modifying the chemical composition (Zn-Al-Mg coatings) or by annealing the zinc coating (galvaannealed coatings) $[3,4]$.

Galvaannealed (Fe-Zn) zinc coatings are made by annealing galvanized steel sheets for several seconds at a temperature of $500-565{ }^{\circ} \mathrm{C}$ in a furnace located at the end of the galvanizing bath [5,6]. Zn-Al-Mg coatings are made by hot dip galvanizing of steels in zinc alloy, containing $0.5 \div 1.0 \% \mathrm{Mg}$ and $0.8 \div 1.0 \% \mathrm{Al}$. The $\mathrm{Mg}$ and $\mathrm{Al}$ elements form a protective stabilizing layer on the surface of the coating, thus enabling the natural protection of the coated material and thus slowing down the corrosion process of the material. Fe- $\mathrm{Zn}$ and $\mathrm{Zn}-\mathrm{Al}-\mathrm{Mg}$ coatings are harder, more scratch resistant, have better weldability, compressibility, paintability and reduce zinc consumption compared to pure zinc coatings $[7,8,9]$. Weldability and formability are important characteristics of Tailored Welded Blanks for car body parts, especially when different steels are welded [10].

The car-body parts - closure (roof, door, trunk lid, fender, deck) and body-in-white - are made by deep drawing, stretching or bending processes. These involve different stress-strain mode and plastic flow due to forces applied when material is deformed. Thus, in the case of coated material, plastic strain causes: thinning the both, base material and coating; failure the coating integrity at the tool-steel sheet surface boundary; cracks formation in the coating when it is not plastic enough; flaking the coating if there is imperfect adhesion to the base material. [11] 


\section{METHODS OF EXPERIMENTS}

The aim of the experiments was to compare the corrosion resistance of hot-dip galvanized sheets with conventional $\mathrm{Zn}$ coating and annealed $\mathrm{Zn}-\mathrm{Al}-\mathrm{Mg}$ coatings of new concepts with different $\mathrm{Al}$ and $\mathrm{Mg}$ contents. Steel sheets were passivated before coating by $40 \div 50 \mathrm{mg} / \mathrm{m}^{2}$ of $\mathrm{Cr}^{3+}$. Chemical composition of coatings and one side surface weight of coating is presented in Table 1.

Table 1 Chemical composition of coatings

\begin{tabular}{|c|c|c|c|}
\hline Coating & $\begin{array}{c}\text { Al } \\
(\mathbf{w t} \%)\end{array}$ & $\begin{array}{c}\mathbf{M g} \\
(\mathbf{w t} \%)\end{array}$ & $\begin{array}{c}\text { One side coating weight } \\
\left(\mathbf{g} / \mathbf{m}^{2}\right)\end{array}$ \\
\hline Zn & 0.63 & - & 82 \\
\hline A1 & 1.53 & 1.26 & 70 \\
\hline A2 & 1.85 & 1.68 & 68 \\
\hline
\end{tabular}

Samples were tested as received and after plastic deformation with different amount of stress and strains made by bending and stretching. During the production of car-body parts by bending and stretching technologies, tensile stresses (tension or tension-tension) are applied. Thus, unwanted events in the coating may occur, such as thinning the coating, abrading the coating on contact surfaces, cracks in the coating due to insufficient plasticity of the coating and peeling the coating off. Bending stresses (tension) were modeled by a three-point bending test up to angle of $90^{\circ}$ and $180^{\circ}$ - (Figure $1 \mathbf{~ b}, \mathbf{c}$ ). Stretching stresses (tensile-tensile) were modeled by the Erichsen test (Figure $1 \mathrm{~d}$ ).

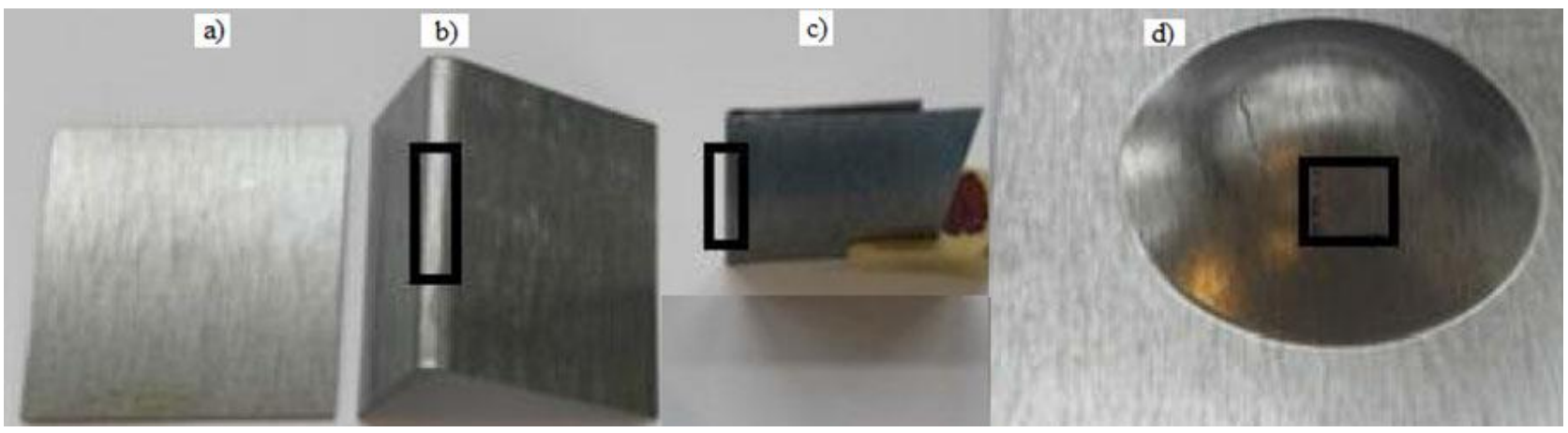

Figure 1 Modelling the stress-strain on the samples

a) as received, b) bending to $90^{\circ}$, c) bending to $180^{\circ}$, d) stretching by Erichsen test

The amount of strains involved in the material by bending and stretching was numerically simulated. Constitutive equations of Hill 48 yield locus and Krupkowski hardening curve were defined for the base material DX54D with thickness $0.8 \mathrm{~mm}$. Results of major and minor strains are shown in (Figure 2) for bending tests up to $90^{\circ}$ and $180^{\circ}$ and Erichsen test. These are shown and compared to the limit strains for base material DX54D in (Figure 3) and possible strains in the car-body components are shown in (Figure 4). As it comes out from numerical simulations of stretching by Erichsen test, the strains were localized and the fracture occurred due to tensile-tensile stresses in the critical cross section. Major and minor strains in this section reached the limit strains $\left(\varepsilon_{1}=0.33\right.$ and $\left.\varepsilon_{2}=0.15\right)$ and plastic properties have been totally utilized. As it comes out from numerical simulations of bending, lower amount of strains has been reached when bending to $90^{\circ}$ $\left(\varepsilon_{1}=0.07\right)$ within the uniform deformation and plastic properties have been utilized only to $23 \%$. The same values were found for bending to $180^{\circ}$, but the wider area has been deformed. 
Bending to $90^{\circ}$
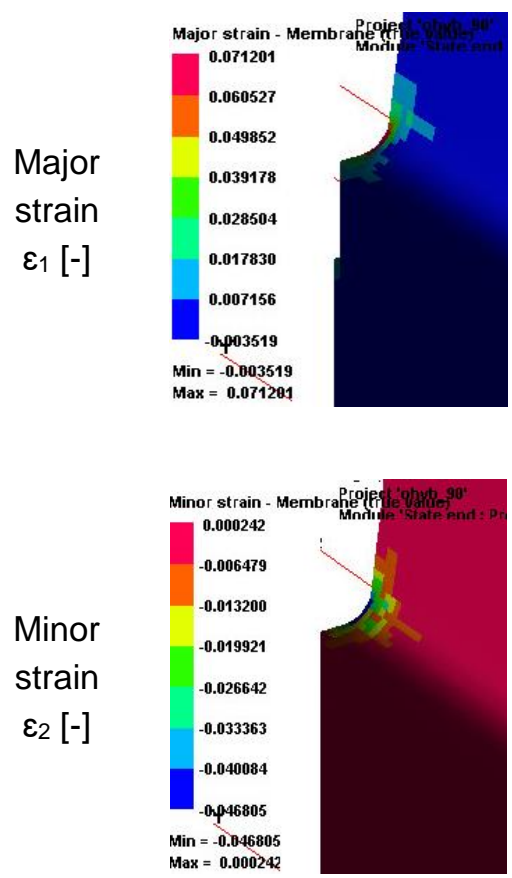

Bending to $90^{\circ}$
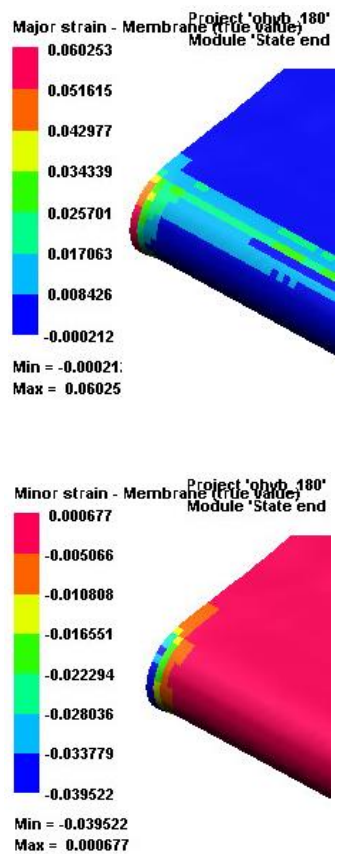

Stretching (Erichsen test)
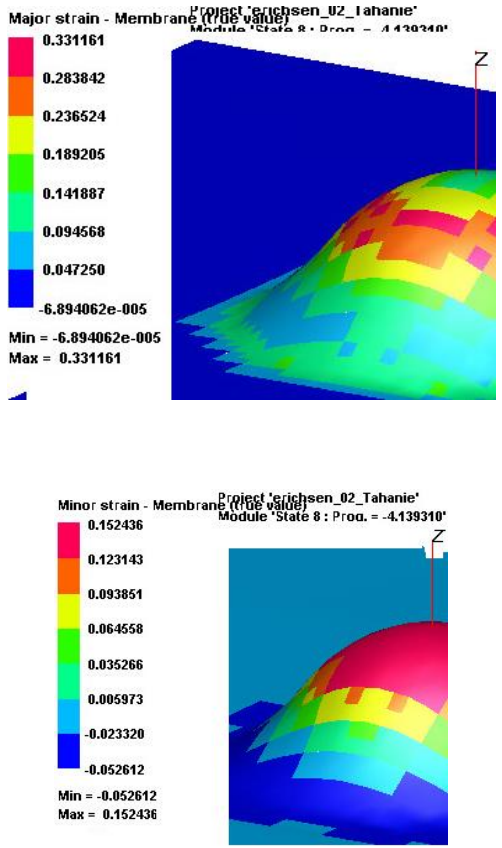

Figure 2 Strain amount in bending and stretching calculated by numerical simulation

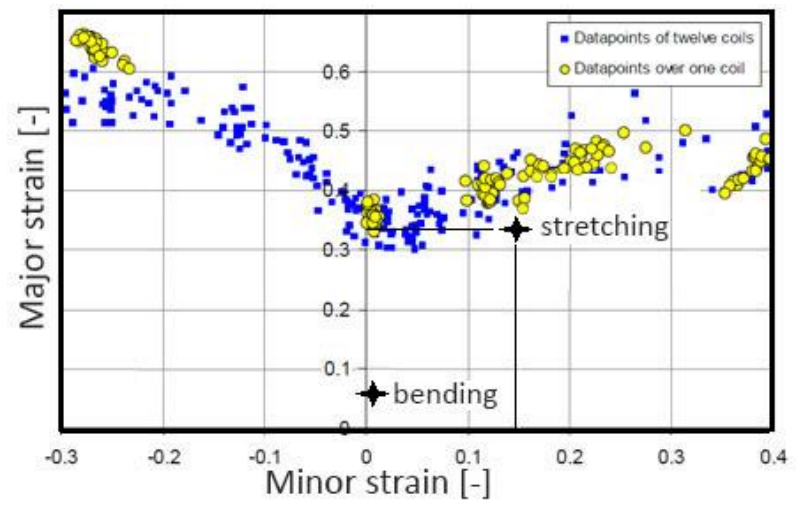

Figure 3 Strains compared to the limit strains for base material DX54D
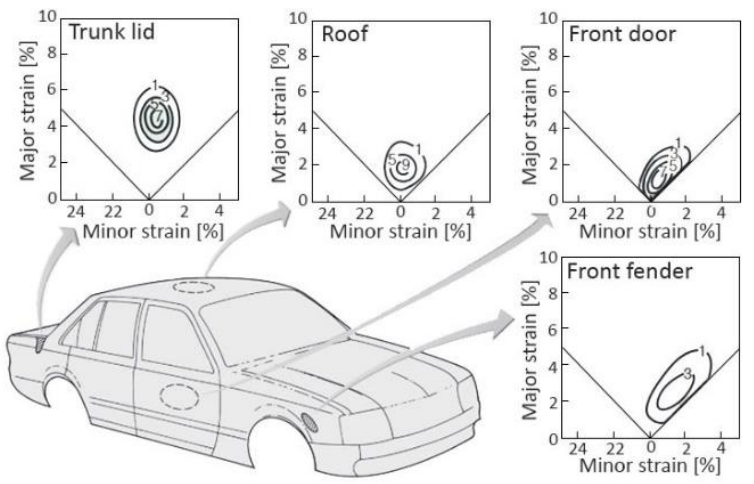

Figure 4 Strains at car-body components

The corrosion resistance of the coated samples before and after deformation was tested according to STN EN ISO 9227 in a corrosion chamber SKBWF - 1000A TR and using salt spray (sodium chloride solution with a concentration of $50 \mathrm{~g} / \mathrm{l}$ ) at a temperature of $35^{\circ} \mathrm{C}$. The samples in the corrosion chamber were not exposed to direct spraying of the salt spray solution. The corrosion resistance of the investigated coatings was monitored depending on the time of red rust appearance and the area of the corroded surface after 24, 48, 72, 120, 144 , $216,312,408,624,724$ and 864 hours spent in the corrosion chamber. Samples after removal from the SKBWF-1000A TR corrosion chamber were cleaned of salt deposits by rinsing. The surface area of the samples affected by corrosion was evaluated using image standards and photographs at different angles. 


\section{RESULTS AND DISCUSSION}

The results of testing until the first formation of the red rust are shown in (Figure 5). The percentage of corroded surface as a function of the time in the corrosive atmosphere is shown in (Figure 6) for Zn coating and in (Figure 7) and (Figure 8) for Zn-Al-Mg coatings. The surface condition after 864 hours is shown in (Figure 9).

Figure 6 shows that the kinetics of corrosion growth have S-shaped curves and can be divided into three phases. The increase in corrosion is more intense in the second phase, when corrosion attacked from about $10 \%$ to about $80 \%$ of the sample area than in the first phase when attacked to about $10 \%$ of the sample area and the third phase when 80 to $100 \%$ of the surface area is corroded.

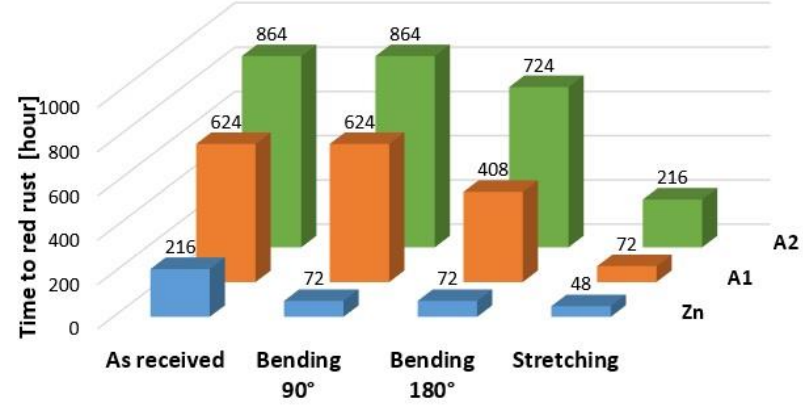

Figure 5 Time until the formation of the red rust

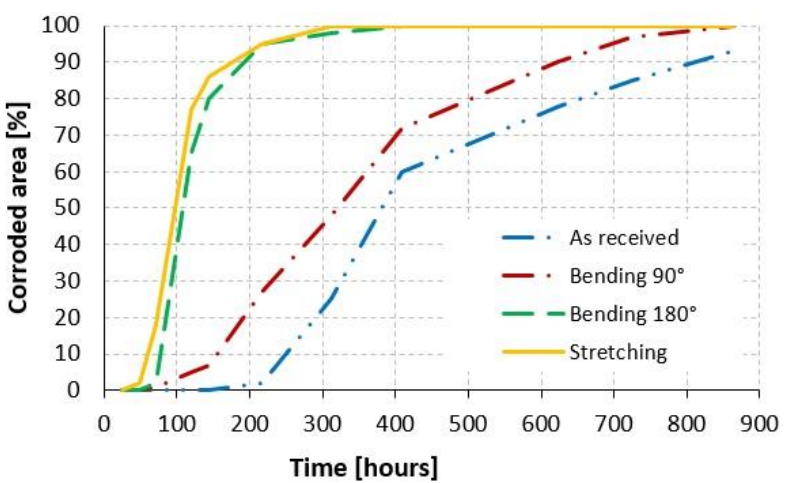

Figure 6 Graph corroded area-time for Zn coating

It can be seen in (Figure 6) that the onset of red rust on as received pure zinc coating was recorded on approximately $2 \%$ of the sample area after 216 hours in the corrosion chamber. With increasing time from 216 hours to 408 hours, the red rust grows more intensively from $2 \%$ to $60 \%$, and from 408 to 864 hours the growth intensity gradually decreases. For samples after bending to $90^{\circ}$ and $180^{\circ}$, the onset of red rust growth was recorded after 72 hours, while for $90^{\circ}$ bending samples, the area affected by corrosion was about $2 \%$ and for $180^{\circ}$ bending was about $4 \%$. In the second phase from 144 to 408 hours, the corrosion spread more intensively on the samples after bending to $180^{\circ}$ and on the samples after stretching by the Erichsen test. The area of the specimens after stretching by the Erichsen test was already $100 \%$ corroded after 312 hours, at a bend to $180^{\circ}$ the area was $100 \%$ infested after 408 hours, at a bending to $180^{\circ}$ the area was corroded to $100 \%$ after 864 hours and in the case of as received samples, even after 864 , there was no $100 \%$ corrosion of the surface. This means that the corrosion resistance of hot-dip galvanized $\mathrm{Zn}$ steel sheets depends on time, deformation and deformed surface at a comparable coating thickness.

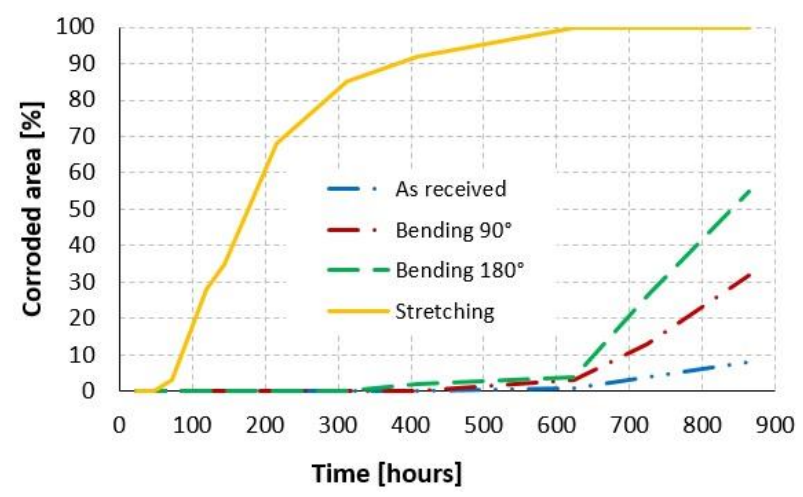

Figure 7 Graph corroded area-time for A1 coating

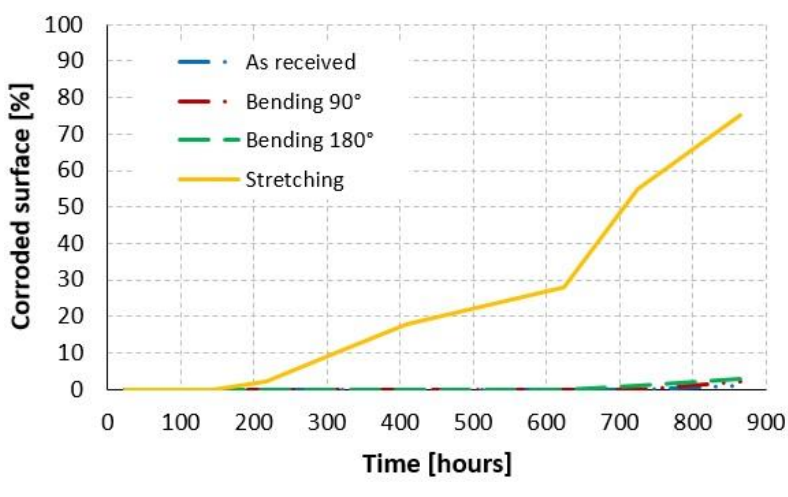

Figure 8 Graph corroded area-time for A2 coating

Figure 7 shows the results of corrosion resistance for $A 1$ coating. It can be seen that the onset of red rust on as received $A 1$ samples was recorded on approximately $2 \%$ of the sample area after 624 hours in the corrosion 
chamber. With increasing time from 624 hours to 864 hours, the red rust grows more intensively from $2 \%$ to $8 \%$. A similar tendency was observed for the samples after bending at $90^{\circ}$ and $180^{\circ}$, with the difference that in the samples after bending to $180^{\circ}$ the red rust growth was more intense than in the samples without deformation and after bending to $90^{\circ}$. In the samples after stretching by the Erichsen test, the onset of corrosion attack was recorded after 72 hours, and after 624 hours, 100\% corrosion attack of the samples occurred.

Figure 8 shows the results of corrosion resistance for A2 coating. It can be seen that the onset of red rust on as received A2 samples and samples after bending to $90^{\circ}$ was the onset of red rust formation after 864 hours in the corrosion chamber. On the samples after bending to $180^{\circ}$ was the onset of red rust formation after 724 hours. When stretched by the Erichsen test, the onset of red rust was recorded after 216 hours and after 864 hours the corroded area of the samples was about $75 \%$. This means that the corrosion resistance of galvanized GA sheets with Zn-Al-Mg coating depends on time, the amount of strain, on the deformed surface with a comparable coating thickness and on the $\mathrm{Al}$ and $\mathrm{Mg}$ content in the coating.

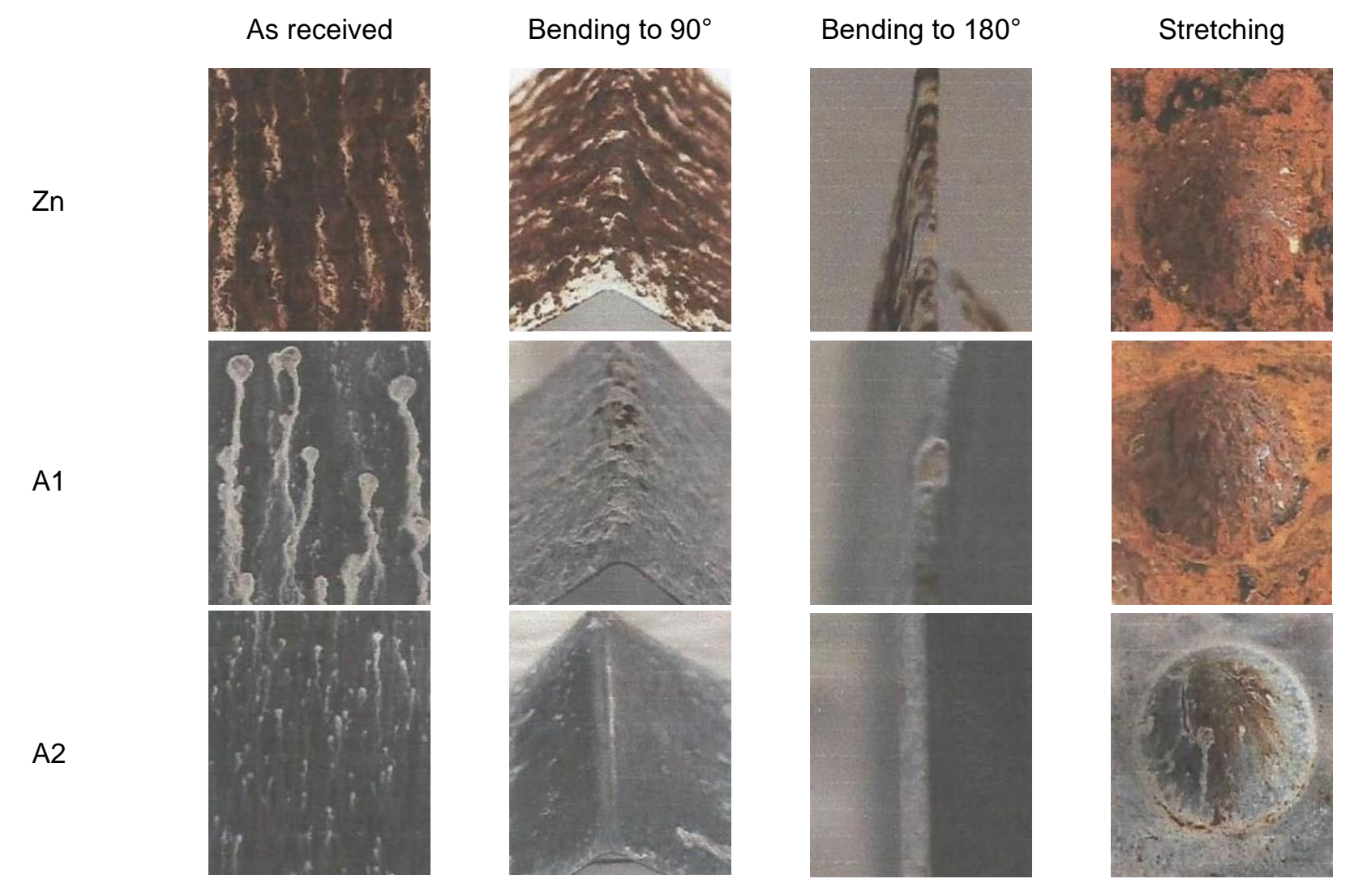

Figure 9 Surface of samples after 864 hours in spent in the corrosion chamber

The results of the experiments show that the onset of the S curves and the time to reach $100 \%$ of the corroded surface shifts to shorter times due to the plastic deformation of the coated steel sheets - for $\mathrm{Zn}$ coating the corrosion resistance deteriorated about $67 \%$ after bending and about $78 \%$ after stretching; for $\mathrm{Zn}-\mathrm{Al}-\mathrm{Mg}$ coatings the corrosion resistance deteriorated about $35 \%$ to $16 \%$ after bending and about $88 \%$ to $35 \%$ after stretching, depending on the amount of $\mathrm{Al}$ and $\mathrm{Mg}$ in the coating. The increase of corrosion resistance for $\mathrm{Zn}$ Al-Mg coating is more visible for different amount of plastic strain:

- for as received samples about $188 \%$ to $300 \%$,

- for samples after bending to $90^{\circ}$ about $767 \%$ to $1100 \%$ and after bending to $180^{\circ}$ about $467 \%$ to $905 \%$,

- for samples after stretching by Erichsen test up to $350 \%$.

It follows from the above that the effect of plastic deformation was less pronounced in the samples with $\mathrm{Zn}-\mathrm{Al}$ $\mathrm{Mg}$ coating. The higher the content of $\mathrm{Al}$ and $\mathrm{Mg}$ in the zinc coating, the more corrosion resistant the material 
is. The different behavior of $\mathrm{Zn}-\mathrm{Al}-\mathrm{Mg}$ coatings compared to conventional $\mathrm{Zn}$ coatings in a corrosive environment can be explained by the fact that the corrosion products form a very thin stable layer of aluminum hydroxide, zinc carbonate $\mathrm{Zn}_{6} \mathrm{Al}_{2},\left(\mathrm{CO}_{3}\right),(\mathrm{OH}) 16.4 \mathrm{H}_{2} \mathrm{O}$ on the surface. This protective layer ensures increased corrosion resistance of coated sheets based on Al-Mg even after their deformation compared to the coated sheets with conventional $\mathrm{Zn}$ coating $[12,13,14]$. This means that if designers avoid multiple bends in the design of body components, minimize the limit deformations on pressings and will make greater use of galvanized sheets with magnesium-aluminum coatings, it is assumed that a significant increase in corrosion resistance of body components.

\section{CONCLUSION}

The results of the experiments show that the onset of the S curves and the time to reach $100 \%$ of the corroded surface shifts to shorter times due to the plastic deformation of the coated steel sheets, depending on the amount of $\mathrm{Al}$ and $\mathrm{Mg}$ in the coating. $\mathrm{Zn}$-Al-Mg coatings improved the corrosion resistance of as received steel sheets 2 to 3 times, but it is more improved after plastic deformation - after bending it is improved about 5 to 10 times and after stretching up to 3.5 times. Thus, it may be concluded the $\mathrm{Zn}$ - $\mathrm{Al}-\mathrm{Mg}$ coated steel sheets preserve the corrosion resistance of the car-body components after plastic deformation.

\section{ACKNOWLEDGEMENTS}

\section{The work has been accomplished under the grant project VEGA 2/0080/19 and project APVV-0273-12.}

\section{REFERENCES}

[1] HAGAROVÁ, M. Povrchové úpravy v automobilovom priemysle. Košice: TU v Košiciach, 2013.

[2] DAVIES, G. Materials for Automobile Bodies. Butterworth-Heinemann, 2012.

[3] GRABAN, J., KOHÚTEKOVÁ, V., HOLLÝ, F., TARHANIČOVÁ, R. Evaluation of galvanized sheets with thin organic coating with antifingerprint properties. In Metal 2008: 17th International Conference on Metallurgy and Materials. Ostrava: TANGER, 2008, pp. 1-7.

[4] COCCO, V., IACOVIELLO, F., D'AGOSTINO, L., NATALI, S. Damage micromechanisms in a hot dip galvanized steel. Procedia Structural Integrity, 2017, vol. 3, pp. 231-236.

[5] POKORNY, P., KOLISKO, J., BALIK, P., NOVAK, P. Description of structure of Fe-Zn intermetallic compounds present in hot-dip galvanized coatings on steel. Metalurgija, 2015, vol.54, no. 4, pp. 707-710.

[6] EVIN, E., TOMÁŠ, M., KOLLÁROVÁ, M., ANTOSZEWSKI, B. Some Tribological aspects of Fe-Zn Coated steel sheets at Stamping Processes. Acta Metallurgica Slovaca, 2014, vol. 20, no. 2, pp. 189-199.

[7] TANAKA, S. et al. The performance of a Zn-Al-Mg-Si hot-dip galvanized steel sheet. In GALVATECH 2001. Brussels: STAHL EISEN, 2001, pp. 153-160.

[8] DUTTA, M., HALDER, A.K., SINGH, S.B. Morphology and properties of hot dip Zn-Mg and Zn-Mg-Al alloy coatings on steel sheet. Surface and Coatings Technology, 2010, vol. 205, iss.7, pp. 2578-2584.

[9] YAO, C., WANG, Z., TAY, S.L., ZHU, T., GAO, W.: Effects of Mg on microstructure and corrosion properties of Zn-Mg alloy. Journal of Alloys and Compounds. 2014, vol. 602, pp. 101-107.

[10] SVEC, P., SCHREK, A., DOMANKOVA, M. Microstructural characteristics of fibre laser welded joint of dual phase steel with complex phase steel. Kovove materialy - Metallic materials, 2018, vol. 56, iss. 1, pp. 29-40.

[11] KOLNEROVÁ, M., SOBOTKA, J., SOLFRONK, P., DOUBEK, P.: Properties of Metal Sheets Surfaces by Manufacturing of Car Body Stampings. In Metal 2007: 16th International Conference on Metallurgy and Materials. Ostrava: TANGER, 2007, pp. 1-6.

[12] NEWMAN, R. C. Environmentally Assisted Cracking Overview. In: COTTIS, B. et al Shreir's Corrosion. Oxford: Elsevier, 2010, pp. 857-863.

[13] SCHÜRZ, S., FLEISCHANDERL, M., MORI, G., STELLNBERGER, K.H., LUCKENEDER, G. H. Corrosion Behavior of Zn-Al-Mg Coated Steel in Different Environments. In CORROSION 2011, Houston - Texas: NACE International, 2011.

[14] DONG, A.; LI, B.; LU, Y.; ZHU, G.; XING, H.; SHU, D.; SUN, B.; WANG, J. Effect of Mg on the Microstructure and Corrosion Resistance of the Continuously Hot-Dip Galvanizing Zn-Mg Coating. Materials, 2017, vol. 10, no. 8. 